\title{
Growth Characteristics of an Oxygen-resistant Hydrogen Bacterium Strain N34
}

\author{
Yoshihiro Nakamura, Jun-ichiro Someya and Jiro Ooyama \\ Fermentation Research Institute, Tsukuba Science City, \\ Tsukuba, Ibaraki 305, Japan \\ Received July 22, 1981
}

\begin{abstract}
The growth characteristics of the oxygen-resistant strain of hydrogen bacterium N34 in a $40 \%$ $\mathrm{O}_{2}$-culture were compared with those in a $4 \% \mathrm{O}_{2}$-culture in order to clarify the mechanism of oxygen-resistance. Growth inhibition was observed with decreased $\mathrm{CO}_{2}$ tension indicating the inhibition of $\mathrm{CO}_{2}$-fixation. Cell growth in $40 \% \mathrm{O}_{2}$-culture was associated with stimulated oxyhydrogen reaction. There was no significant difference in cell composition. Each of the efficiency of energy conversion and the yield coefficients, $Y_{\mathrm{H}_{2}}$ and $Y_{\mathrm{O}_{2}}$, in the $40 \% \mathrm{O}_{2}$-culture was about half of that in the $4 \% \mathrm{O}_{2}$-culture. The yield coefficient, $Y_{\mathrm{CO}_{2}}$, or the carbon recovery, however, was almost equal between the two kinds of cultures. The mechanism of oxygen-resistance was discussed.
\end{abstract}

It seems to be a general phenomenon that high oxygen tension inhibits the cell growth of hydrogen bacteria; the majority of hydrogen bacteria are unable to grow under more than $40 \% \mathrm{O}_{2} .{ }^{1)}$ Some hydrogen bacteria, as exceptions, were reported to be able to grow under high oxygen tension, ${ }^{2,3)}$ but the mechanisms of the oxygen-resistance in these organisms have not been mentioned yet. The growth inhibition by high oxygen tension has been considered to be the result of the high oxygen-sensitivity of hydrogenase $\mathrm{e}^{4)}$ and many attempts to stabilize or protect hydrogenase against oxygen inactivation have been reported. ${ }^{5 \sim 9)}$ It has been reported that high oxygen tension also represses hydrogenase formation. ${ }^{10 \sim 13)}$

Oxygen-resistant hydrogen bacterium strain $\mathrm{N} 34,{ }^{14)}$ capable of cell growth under $40 \% \mathrm{O}_{2}$ without a growth lag phase, was obtained by the adaptation of oxygen-sensitive strain $\mathrm{N} 34^{15)}$ to $40 \% \mathrm{O}_{2}$. Recently, the adaptation of growing cultures of Chlorella ${ }^{16)}$ to $80 \% \mathrm{O}_{2}$ was reported and it was assumed to be a phenotypic change.

We have previously described ${ }^{17)}$ that the hydrogen-oxidizing system was not protected from the influence of $40 \% \mathrm{O}_{2}$ in oxygenresistant resting cells and that the hydrogenase formation system seemed to be protected from oxygen inhibition in the oxygen-resistant proliferating cells.

The present paper deals with comparisons of growth characteristics between $4 \% \mathrm{O}_{2}$ - and $40 \% \mathrm{O}_{2}$-cultures of oxygen-resistant hydrogen bacterium strain $\mathrm{N} 34^{14}$ ) to clarify the mechanisms of the oxygen-resistance.

\section{MATERIALS AND METHODS}

Organism. Oxygen-resistant hydrogen bacterium strain $\mathrm{N} 34^{14}$ ) obtained by the adaptation of oxygen-sensitive strain N34 to high oxygen tension was used for the investigations.

Culture medium and growth conditions. The medium used for the autotrophic culture was composed of $\mathrm{KH}_{2} \mathrm{PO}_{4} 300 \mathrm{mg} ; \mathrm{K}_{2} \mathrm{HPO}_{4} 400 \mathrm{mg}$; urea $1 \mathrm{~g} ; \mathrm{MgSO}_{4}$. $7 \mathrm{H}_{2} \mathrm{O} \quad 200 \mathrm{mg} ; \quad \mathrm{FeSO}_{4} \cdot 7 \mathrm{H}_{2} \mathrm{O} \quad 50 \mathrm{mg} ; \quad \mathrm{ZnSO}_{4} \cdot 7 \mathrm{H}_{2} \mathrm{O}$ $0.05 \mathrm{mg} ; \mathrm{Na}_{2} \mathrm{MoO}_{4} \cdot 2 \mathrm{H}_{2} \mathrm{O} 0.1 \mathrm{gm}$, made up to 1 liter with distilled water. The solution of urea was filter-sterilized (membrane filter, $0.2 \mu \mathrm{m}$ pore size) and added aseptical1y. The seed culture was carried out on agar plate medium under an atmosphere of $80 \% \mathrm{H}_{2}+10 \% \mathrm{O}_{2}+10 \% \mathrm{CO}_{2}$. Cultivation was performed in 1 liter-suction flasks containing $10 \mathrm{ml}$ of the medium. After inoculation, flasks were evacuated, refilled with gas-mixtures of various compositions and shaken reciprocally $(120 \mathrm{rpm}$, stroke length $7 \mathrm{~cm}$ ) at $35^{\circ} \mathrm{C}$. The gas phase was not replaced during cultivation.

Measurement of growth. Cell growth was determined by 
measuring the optical density with a photometer (Shimadzu made Baush \& Lomb Spectronic 20 model) at $450 \mathrm{~nm}$. The specific growth rate, $\mu_{\max }$, was estimated during the exponential growth phase.

Measurement of dry cell weight. The dry cell weight of washed cells was measured after the weight had reached a constant value on drying at $105^{\circ} \mathrm{C}$.

Analysis of cell composition. Elemental analysis was done with a CHN analyzer (Yanagimoto, Type M-2). Protein content was determined by Lowry's method. ${ }^{18)}$ Analysis of poly- $\beta$-hydroxy butyrate (PHB) was carried out by the method described by Law et al. ${ }^{19)}$

Analysis of gases. The composition of the gas phase in. the flask before and after the cultivation was determined with a gas chromatograph (Shimadzu Type GC-4B) as described in the previous paper. ${ }^{1)}$ The consumption of $\mathrm{H}_{2}$, $\mathrm{O}_{2}$ and $\mathrm{CO}_{2}$ was estimated as the difference between the initial and the final composition of the gas phase.

\section{RESULTS}

Effects of oxygen tension on growth rate and cell yield

Table I shows the effects of oxygen tension on growth rate and cell yield of oxygenresistant strain N34. Cell growth occurred without a lag period under $10 \% \sim 60 \% \mathrm{O}_{2}$, but both the growth rate and the cell yield were depressed markedly with increased oxygen tension. Gaseous substrates had not been exhausted at the stationary growth phase in each flask. Moreover, the resumption of cell growth occurred when the gas phase was replaced with a gas-mixture of $92 \% \mathrm{H}_{2}+4 \% \mathrm{O}_{2}+4 \% \mathrm{CO}_{2}$ at the stationary growth phase in each flask. These results indicate that the cell growth ceased not due to the deficiency of the substrates or inorganic nutrient sources but to the inhibition effects of oxygen.

\section{Effect of hydrogen tension on growth rate}

The effect of hydrogen tension on the growth rate of oxygen-resistant strain N34 was tested both under $4 \%$ and $40 \% \mathrm{O}_{2}$. The growth rate was not affected by the increased hydrogen tension.

\section{Effects of carbon dioxide tension on growth rate}

As shown in Table II, a positive correlation
TABle I. EfFect of Oxygen Tension ON Growth Rate and Cell Yield of OXYGEn-Resistant STRain N34

\begin{tabular}{ccccc}
\hline \multicolumn{2}{c}{ Gas composition $(\%)$} & $\begin{array}{c}\text { Growth rate } \\
\mu\left(\mathrm{hr}^{-1}\right)\end{array}$ & $\begin{array}{c}\text { Dry cell weight } \\
(\mathrm{mg} / \mathrm{ml})\end{array}$ \\
\cline { 1 - 2 } $\mathrm{H}_{2}$ & $\mathrm{O}_{2}$ & $\mathrm{CO}_{2}$ & & \\
\hline 86 & 10 & 4 & 0.226 & 5.13 \\
76 & 20 & 4 & 0.168 & 4.06 \\
66 & 30 & 4 & 0.153 & 2.37 \\
56 & 40 & 4 & 0.116 & 1.53 \\
46 & 50 & 4 & 0.097 & 0.94 \\
36 & 60 & 4 & 0.035 & 0.35 \\
\hline
\end{tabular}

a Cells were harvested at the end of the culture.

Table II. Effect of Carbon Dioxide Tension on Growth Rate of OXYGEN-RESISTANT STRAIN N34

$\mathrm{H}_{2}$ tension was $86 \%$ and $50 \%$ in the $4 \% \mathrm{O}_{2}-$ and $40 \%$ $\mathrm{O}_{2}$-cultures, respectively.

\begin{tabular}{ccc}
\hline \multirow{2}{*}{$\begin{array}{c}\mathrm{CO}_{2} \text { tension } \\
(\%)\end{array}$} & \multicolumn{2}{c}{ Growth rate, $\mu\left(\mathrm{hr}^{-1}\right)$ under } \\
\cline { 2 - 3 } & $4 \% \mathrm{O}_{2}$ & $40 \% \mathrm{O}_{2}$ \\
\hline 0.5 & 0.108 & 0.068 \\
1 & 0.139 & 0.088 \\
2 & 0.164 & 0.103 \\
10 & 0.187 & 0.120 \\
\hline
\end{tabular}

exists between the initial $\mathrm{CO}_{2}$ tension in the gas phase and the specific growth rate; growth inhibition with decreased $\mathrm{CO}_{2}$ tension was observed.

\section{Comparison of cell compositions}

The elemental composition of the cell mass was analyzed as shown in Table III. There were no significant differences in elemental composition between the two kinds of cells. The protein content was higher in the $40 \% \mathrm{O}_{2}$ grown cells, while the PHB content was higher in the $4 \% \mathrm{O}_{2}$-grown cells.

\section{Comparison of material balance}

Material balances in $4 \% \mathrm{O}_{2}$ - and $40 \% \mathrm{O}_{2}$ cultures of oxygen-resistant strain N34 are summarized in Table IV.

The theoretical stoichiometry of gas consumption is as follows; 


$$
\begin{gathered}
2 n \mathrm{H}_{2}+n \mathrm{O}_{2}=2 n \mathrm{H}_{2} \mathrm{O} \\
2 \mathrm{H}_{2}+\mathrm{CO}_{2}=\mathrm{CH}_{2} \mathrm{O}+\mathrm{H}_{2} \mathrm{O} \\
(1)+(2), 2(n+1) \mathrm{H}_{2}+n \mathrm{O}_{2}+\mathrm{CO}_{2} \\
=\mathrm{CH}_{2} \mathrm{O}+(2 n+1) \mathrm{H}_{2} \mathrm{O}
\end{gathered}
$$

from (3),

$$
n=\frac{\text { consumed } \mathrm{H}_{2}\left(\text { ratio to } \mathrm{CO}_{2}\right)}{2}-1
$$

\begin{tabular}{|c|c|c|}
\hline & \multicolumn{2}{|c|}{ Oxygen tension } \\
\hline & $4 \%$ & $40 \%$ \\
\hline Element $(\%) \mathrm{C}$ & 48.11 & 46.64 \\
\hline $\mathrm{H}$ & 7.31 & 6.88 \\
\hline $\mathrm{O}^{a}$ & 28.09 & 29.30 \\
\hline $\mathrm{N}$ & 9.65 & 10.93 \\
\hline Ash & 6.84 & 6.25 \\
\hline Protein $(\%)$ & 57.9 & 65.5 \\
\hline PHB $(\%)$ & 1.8 & 1.3 \\
\hline
\end{tabular}

Table III. Cell Composition of OxygenRESISTANT N34 GROWN UNDER $4 \% \mathrm{O}_{2}$ AND $40 \% \mathrm{O}_{2}$

\begin{tabular}{|c|c|c|}
\hline & \multicolumn{2}{|c|}{ Oxygen tension } \\
\hline & $4 \%$ & $40 \%$ \\
\hline Gas consumption (ml) $\mathrm{H}_{2}$ & 145.4 & 91.4 \\
\hline $\mathrm{O}_{2}$ & 58.2 & 40.9 \\
\hline $\mathrm{CO}_{2}$ & 26.4 & 8.7 \\
\hline Ratio $\left(\mathrm{H}_{2}: \mathrm{O}_{2}: \mathrm{CO}_{2}\right)$ & $5.5: 2.2: 1$ & $10.5: 4.7: 1$ \\
\hline Cell yield (dry wt. mg) & 21.2 & 6.4 \\
\hline Yield coefficient, ${ }^{a} Y_{\mathrm{H}_{2}}$ & 1.63 & 0.78 \\
\hline$(\mathrm{g} / \mathrm{g}) \quad Y_{\mathrm{O}_{2}}$ & 0.26 & 0.11 \\
\hline$Y_{\mathrm{CO}_{2}}$ & 0.41 & 0.37 \\
\hline Carbon recovery ${ }^{b}(\%)$ & 72.0 & 63.9 \\
\hline $\begin{array}{l}\text { Efficiency of energy } \\
\text { conversion, } Y_{\mathrm{E}}{ }^{c}(\%)\end{array}$ & 28.0 & 13.4 \\
\hline
\end{tabular}

a Oxygen content was calculated as residue.

Table IV. Growth Characteristics of OXYGenRESiStant STRAin N34 IN $4 \% \mathrm{O}_{2}$ AND $40 \% \mathrm{O}_{2}$-CULTURES

a Yield coefficients were calculated by dividing the dry cell weight produced by the weight of gaseous substrate consumed.

$b$ Carbon recovery was calculated as the percentage of cell-C to consumed $\mathrm{CO}_{2}-\mathrm{C}$.

c $\quad Y_{\mathrm{E}}=\frac{\text { produced cells }(\mathrm{mg}) \times 4.85}{\text { consumed } \mathrm{H}_{2}(\mathrm{mmol}) \times 56.5} \times 100$
When observed values of consumed $\mathrm{H}_{2}$ (ratio to consumed $\mathrm{CO}_{2}$ ) shown in Table IV are put into eq. (4), $n$ is calculated to be 1.75 and 4.25 in the $4 \% \mathrm{O}_{2}$ - and $40 \% \mathrm{O}_{2}$-cultures, respectively. The other values of $n$, based on consumed $\mathrm{O}_{2}$ (ratio to consumed $\mathrm{CO}_{2}$ ), 2.2 and 4.7 (Table IV), are larger than the calculated ones, respectively, showing that cell growth of oxygen-resistant strain N34 is associated with the stimulated oxygen uptake. Furthermore, the ratio of consumed $\mathrm{H}_{2}+\mathrm{O}_{2}$ in the $40 \% \mathrm{O}_{2}$-culture was twice as much than that in the $4 \% \mathrm{O}_{2}$-culture and the difference between the two cultures was $5 \mathrm{H}_{2}+2.5 \mathrm{O}_{2}$.

Yield coefficients, $Y_{\mathrm{H}_{2}}$ and $Y_{\mathrm{O}_{2}}$, in the $40 \%$ $\mathrm{O}_{2}$-culture are approximately half of those in the $4 \% \mathrm{O}_{2}$-culture, while $Y_{\mathrm{CO}_{2}}$ are almost equal to each other.

The carbon recoveries with respect to the percentage of the cell- $\mathrm{C}$ to the consumed $\mathrm{CO}_{2}-$ $\mathrm{C}$ are also almost equal to each other as for $Y_{\mathrm{CO}_{2}}$ above.

The efficiency of energy conversion, $Y_{\mathrm{E}}$, was estimated as the percentage of the combustion heat of produced cells $(4.85 \mathrm{kcal} / \mathrm{g})$ to that of consumed $\mathrm{H}_{2}(56.5 \mathrm{kcal} / \mathrm{mol}) .{ }^{20)}$ As shown in Table IV, $Y_{\mathrm{E}}$ in the $40 \% \mathrm{O}_{2}$-culture is about half of that in the $4 \% \mathrm{O}_{2}$-culture.

\section{DISCUSSION}

Growth inhibition was observed with decreased $\mathrm{CO}_{2}$ tension (Table II). There are few data on the effect of $\mathrm{CO}_{2}$ tension on the cell growth of hydrogen bacteria. ${ }^{21 \sim 25)}$ A positive correlation between the initial partial pressure of $\mathrm{CO}_{2}$ and the specific growth rate was reported for thermophilic hydrogen bacterium strain $\mathrm{TH}-1$, and the dependence of the physiology of strain $\mathrm{TH}-1$ on the partial pressure of $\mathrm{CO}_{2}$ was speculated. ${ }^{23)}$ Recently, the inhibition of $\mathrm{CO}_{2}$-fixation was observed under low $\mathrm{CO}_{2} /$ high $\mathrm{O}_{2}$ conditions with Alcaligenes eutrophus $^{25}$ as it was assumed to be due to the oxygenase function of ribulose 1,5-bisphosphate carboxylase. The growth inhibition observed with decreased $\mathrm{CO}_{2}$ tension in strain N34 seems likely to be accounted for by the 
inhibition of $\mathrm{CO}_{2}$-fixation. That $Y_{\mathrm{CO}_{2}}$ or the carbon recovery was almost equal in both $4 \%$ $\mathrm{O}_{2}$ - and $40 \% \mathrm{O}_{2}$-cultures (Table IV) shows that the process of cell yield next to the incorporation of $\mathrm{CO}_{2}$ was not affected by oxygen tension. Thus, the inhibition of $\mathrm{CO}_{2}$ fixation is presumed to be one possible factor of the depression of the cell yield under high oxygen tension shown in Table I.

The elemental composition of $\mathrm{C}, \mathrm{H}, \mathrm{O}$ and $\mathrm{N}$ shown in Table III is similar to that of other hydrogen bacteria. ${ }^{20,26)}$ That the PHB content was higher in the $4 \% \mathrm{O}_{2}$-grown cells (Table III) is due to the oxygen deficiency ${ }^{27)}$ at the end of the $4 \% \mathrm{O}_{2}$-culture.

With respect to the gas consumption, the observed value of consumed $\mathrm{O}_{2}$ was higher than the calculated one (Table IV). But it is uncertain whether or not this observation supports the existence of the respiratory protection system (if any) as described for Azotobacter. $^{28)}$ It seems a rather general phenomenon in the growth of hydrogen bacteria that the observed $\mathrm{O}_{2}$ consumption is greater than the calculated one, because the ratio of observed gas composition in Pseudomonas hydrogenovora ${ }^{20)}$ and Alcaligenes hydrogenophilus ${ }^{26)}$ also shows higher consumption of $\mathrm{O}_{2}$ than calculated from eq. (3).

As already mentioned in the introduction, the hydrogenase synthesizing system was presumed to be protected from the influence of high oxygen tension in proliferating cells of oxygen-resistant strain $\mathrm{N} 34 .{ }^{17)}$ In the $40 \% \mathrm{O}_{2}$ culture, the augmented oxyhydrogen reaction presumably scavenges the excess $\mathrm{O}_{2}$ resulting in the protection of the hydrogenase synthesizing system.

\section{REFERENCES}

1) M. Aggag and H. G. Schlegel, Arch. Mikrobiol., 88, 299 (1973).

2) N. Tunail and H. G. Schlegel, Arch. Mikrobiol., 100, 341 (1974).

3) T. Kodama, Y. Igarashi and Y. Minoda, Agric. Biol.
Chem., 39, 77 (1975).

4) H. F. Fisher, A. I. Krasna and D. Rittenberg, J. Biol. Chem., 209, 569 (1954).

5) T. Yagi, "Biological Solar Energy Conversion," ed. by A. Mitsui, S. Miyachi, A. S. Pietro and S. Tamura, Academic Press Inc., New York, N.Y., 1977, p. 61.

6) T. Kakuno, H. Hiura, J. Yamashita, R. G. Bartsh and T. Horio, J. Biochem., 84, 1649 (1978).

7) A. M. Klibanov, N. O. Kaplan and M. D. Kamen, Biochim. Biophys. Acta, 547, 411 (1979).

8) N. A. Zorin, I. N. Gogotov and E. N. Kondratieva, FEMS Microbiol. Lett., 5, 301 (1979).

9) H. M. van der Westen, S. G. Mayhew and C. Veeger, FEMS Microbiol. Lett., 7, 35 (1980).

10) E. Wilson, H. A. Stout, D. Powelson and H. Koffler, J. Bacteriol., 65, 283 (1953).

11) M. Aragno and H. G. Schlegel, Arch. Microbiol., 116, 221 (1978).

12) H. Berndt and D. Wölfe, "Hydrogenases: Their Catalytic Activity, Structure and Function," ed. by H. G. Schlegel and K. Schneider, Erich Goltze K. G., Böttingen, 1978, p. 327.

13) M. Pinkwart, H. Bahl, M. Reimer, D. Wölfe and H. Berndt, FEMS Microbiol. Lett., 6, 177 (1979).

14) Y. Nakamura, J. Someya and J. Ooyama, Agric. Biol. Chem., 43, 1825 (1979).

15) J. Ooyama, Rep. Ferment. Res. Inst., 39, 41 (1971).

16) M. W. Pirt and S. J. Pirt, J. Gen. Microbiol., 119, 321 (1980).

17) Y. Nakamura, J. Someya and J. Ooyama, Rep. Ferment. Res. Inst., 53, 1 (1979).

18) O. H. Lowry, N. J. Rosebrough, A. L. Farr and R. J. Randall, J. Biol. Chem., 193, 265 (1951).

19) J. H. Law and R. A. Slepecky, J. Bacteriol., 82, 33 (1961).

20) T. Kodama, Y. Igarashi and Y. Minoda, Agric. Biol. Chem., 39, 83 (1975).

21) L. Bongers, J. Bacteriol., 104, 145 (1970).

22) R. Repaske, C. A. Ambrose, A. C. Repaske and M. L. Delacy, J. Bacteriol., 107, 712 (1971).

23). E. Goto, T. Kodama and Y. Minoda, Agric. Biol. Chem., 41, 685 (1977).

24) Y. Morinaga, S. Yamanaka, A. Ishizaki and $Y$. Hirose, Agric. Biol. Chem., 42, 439 (1978).

25) W. R. King and K. Andersen, Arch. Microbiol., 128, 84 (1980).

26) K. Ohi, T. Nishimura, M. Okazaki and Y. Miura, $J$. Ferment. Technol., 57, 203 (1979).

27) E. Schuster and H. G. Schlegel, Arch. Mikrobiol., 58, 380 (1967).

28) M. G. Yates and C. W. Jones, Adv. Microbiol. Physiol., 11, 97 (1974). 